DOI: $10.15290 /$ aipan.2020.13

\title{
Zakaz dyskryminacji ze względu na wyposażenie genetyczne a prawne granice medycznego wspomagania prokreacji
}

Małgorzata Gałązka

Katolicki Uniwersytet Lubelski Jana Pawła II

mkinga@kul.pl

ORCID: https://orcid.org/0000-0002-9433-4356

\section{Medyczne wspomaganie prokreacji wobec chorób uwarunkowanych genetycznie}

Zakres prawnych problemów niepełnosprawności w dużej mierze wytyczany jest rozwojem wiedzy medycznej i jej możliwych zastosowań. W obszarze niepełnosprawności uwarunkowanej genetycznie na uwagę z tej perspektywy zasługują procedury medycznego wspomagania prokreacji, które otwiera możliwości diagnozowania ludzkiego wyposażenia genetycznego oraz oddziaływania na nie w najwcześniejszej fazie życia lub przed poczęciem. Upatruje się w tym szansę przeciwdziałania chorobom uwarunkowanym genetycznie, wobec których współczesna medycyna jest bezradna lub którym może zaradzić tylko objawowo. Możliwości te obejmują dwie grupy interwencji medycznych: genoterapię komórek linii rozrodczej i diagnostykę genetyczną.

Do pierwszej należą działania przyczynowe, polegające - ujmując rzecz ogólnie - na eliminacji wadliwego genu lub zastapieniu go przez prawidłowy. Mają one charakter eksperymentalny i obecnie są podejmowane zasadniczo na komórkach spoza linii rozrodczej (somatycznych), co ogranicza zakres wprowadzanych zmian do organizmu pacjenta bez skutków dla następnych pokoleń i zazwyczaj przynosi korzyści jedynie przejściowo ${ }^{1}$. Genoterapia komórek linii rozrodczej, obejmują-

Zob. S. Misra, Human gene therapy: a brief overview of the genetic revolution, „Association of Physicians of India” 2013, nr 2, s. 127, 131-132; M. Barańska, J. Skrętowicz, Perspektywy terapii genowej, „Wiadomości 
ca komórki rozrodcze i wczesnoembrionalne, pozwalałaby na uzyskanie efektów trwałych i dziedzicznych, definitywnie eliminując wadę genetyczną. Wiąże się jednak z wyższym ryzykiem, ponieważ równie radykalne mogą okazać się ewentualne skutki uboczne ${ }^{2}$. Na znacznie szerszą skalę wykorzystywane są obecnie w prokreacji medycznie wspomaganej możliwości diagnostyki genetycznej, szczególnie diagnostyki przedimplantacyjnej embrionu in vitro. W tym celu pobiera się do analizy genetycznej 1-2 komórki od embrionu 3-dniowego albo większą liczbę komórek od co najmniej 5-dniowego embrionu ${ }^{3}$. Za bezpieczną lub bezpieczniejszą dla embrionu uznawana jest ta druga, młodsza metoda, podczas gdy w pierwszej dostrzega się ryzyko zaburzeń rozwojowych ${ }^{4}$. W praktyce medycznej zakres zaburzeń uznawanych za wskazanie dla diagnostyki przedimplantacyjnej sukcesywnie się poszerza. Początkowo ograniczano je do chorób jednogenowych, z czasem jednak objęły też zaburzenia chromosomalne i predyspozycje do chorób wieloczynnikowych ${ }^{5}$. Ze względu na wspomniane ograniczenia w genoterapii komórek linii rozrodczej diagnostyka przedimplantacyjna - w odróżnieniu od badań prenatalnych w czasie ciąży ${ }^{6}$ - służy jednak wyłącznie selekcji embrionów, prowadzącej do umieszczenia w organizmie kobiety wyłącznie embrionów wolnych od wad genetycznych ${ }^{7}$.

Z perspektywy prawnej, podobnie jak bioetycznej, selekcyjny charakter diagnostyki przedimplantacyjnej wymaga konfrontacji z zakazem dyskryminacji ze

Lekarskie" 2007, nr 7-8, s. 307-310; G. Narayanan et al., Clinical development of gene therapy needs a tailored approach: a regulatory perspective from the European Union, „Human Gene Therapy Clinical Development 2014", nr 1, s. 1.

2 Zob. J.-F. Mattei, Les avancées de la génétique, [w:] Philosophie, éthique et droit de la médecine, red. D. Folscheid, B. Feuillet-Le Mintier, J.-F. Mattei, Paris 1997, s. 464-465; G. Narayanan et al., Clinical, s. 6. Istnienie takiego ryzyka bywa w literaturze medycznej kwestionowane; zob. J. E. Lunsho, Human germ line editing - roles and responsibilities, „Protein Cell” 2016, nr 7, s. 7-10. Na temat podejmowania takich prób zob. tamże; M. Soniewska, Selekcja genetyczna w prokreacji medycznie wspomaganej. Etyczne i prawne kryteria, Warszawa 2018, s. 23-26.

3 Zob. A A. Theodosiou, M.H. Johnson, The politics of human embryo research and the motivation to achieve PGD, „Reproductive BioMedicine Online” 2011, nr 22(5), s. 457-462; G. Harton et al., ESHRE PGD Consortium/Embryology Special Interest Group - best practice guidelines for polar body and embryo biopsy for preimplantation genetic diagnosis/screening (PGD/PGS), „Human Reproduction” 2011, nr 1, s. 42.

Zob. A. Kuliev, Y. Verlinsky, Preimplantation genetic diagnosis: technological advances to improve accuracy and range of applications, „Reproductive BioMedicine Online” 2008, nr 4, s. 536, www.rbmojournal.com; G. Harton et al., ESHRE PGD..., s. 42-43; L. Lu et al., Recent advances in preimplantation genetic diagnosis and screening, „Journal of Assisted Reproduction and Genetics” 2016, nr 9, s. 1130, 1132; D. Cimadomo et al., The impact of biopsy on human embryo developmental potential during preimplantation genetic diagnosis, „BioMed Research International” 2016, article ID 7193075, s. 1-7, https://www.hindawi.com/journals/bmri. Zob. A. Kuliev, Y. Verlinsky, Thirteen years' experience of preimplantation diagnosis: report of the Fifth International Symposium on Preimplantation Genetics, „Reproductive BioMedicine Online” 2003, nr 2, s. 230. Wynik badań prenatalnych może ale nie musi prowadzić do przerwania ciąży, możliwe są też działania zmierzające do poprawy stanu zdrowia dziecka już w fazie płodowej; zob. np. D. Folscheid, J.-J. Wunenburger, La vie commençante, [w:] Philosophie, éthique et droit de la médecine, red. D. Folscheid, B. Feuillet-Le Mintier, J.-F. Mattei, Paris 1997, s. 207. 2010, nr 3, s. 280; A.A. Theodosiou, M.H. Johnson, The politics of human..., s. 457-462; G. Harton et al., ESHRE PGD..., s. 42. 
Zakaz dyskryminacji ze względu na wyposażenie genetyczne...

względu na wyposażenie genetyczne, wywodzonym z równej godności każdego człowieka. Potencjał dyskryminacyjny w mniejszym stopniu cechuje genoterapię komórek linii rozrodczej, ocenianą głównie w kategoriach ryzyka nieodwracalnych modyfikacji genetycznych. Może się on jednak ujawnić wraz z szerszym zastosowaniem tego rodzaju interwencji, szczególnie na gruncie kryteriów celu, dostępu lub postępowania z embrionami niezakwalifikowanymi do genoterapii. Nie jest też wykluczone, że w przyszłości dostęp do względnie bezpiecznej genoterapii wczesnego embrionu ograniczy selekcyjne zastosowanie diagnostyki przedimplantacyjnej, otwierając perspektywę korzystania z niej dla realizacji celów leczniczych.

\section{Perspektywa prawnoczłowiecza}

Wolność od dyskryminacji ze względu na wyposażenie genetyczne należy do podstawowych praw człowieka, chronionych na gruncie międzynarodowym. Stanowi kontynuację i rozwinięcie zakazów antydyskryminacyjnych opartych na otwartych katalogach kryteriów ${ }^{8}$, wśród których cechy genetyczne są niekiedy wymieniane wyraźnie 9 . Szczególne miejsce znalazła w traktatach Rady Europy, będących podstawą ochrony praw człowieka wobec rozwoju biologii i medycyny. Europejska konwencja o prawach człowieka i biomedycynie ${ }^{10}$, wraz z Protokołem dodatkowym z 2008 r. dotyczącym testów genetycznych dla celów zdrowotnych ${ }^{11}$, nakładają na państwa-strony obowiązek ochrony istoty ludzkiej w jej godności i tożsamości oraz zagwarantowania każdej osobie, bez dyskryminacji, poszanowania jej integralności oraz innych podstawowych praw i wolności wobec zastosowań biologii i medycyny (art. 1 ust. 1 EKB), w szczególności zaś testów genetycznych (art. 1 Protokołu IV). Odrębnie zaś proklamują zakaz jakiejkolwiek dyskryminacji osoby ze względu na jej wyposażenie genetyczne (art. $11 \mathrm{EKB}$ ) - czy to jako jednostki, czy to jako członka grupy (art. 4 ust. 1 Protokołu IV).

Zasadniczą kwestią z perspektywy diagnostyki przedimplantacyjnej jest ustalenie, czy zakaz dyskryminacji genetycznej ma zastosowanie na etapie embrionalnym. W literaturze nawet autorzy, którzy nie wykluczają dopuszczalności selekcji przedurodzeniowej motywowanej stanem zdrowia embrionu lub płodu, dostrzegają w badaniach przedimplantacyjnych przejawy dyskryminacji ze względu na wy-

8 Zob. art. 14 Europejskiej konwencji praw człowieka, art. 32 ust. 2 Konstytucji RP.

9 Zob. art. 21 ust. $1 \mathrm{KPP}$ oraz wiele aktów prawa wtórnego UE, np. motyw 21 dyrektywy Parlamentu Europejskiego i Rady 2008/115/WE z dnia 16 grudnia 2008 r. w sprawie wspólnych norm i procedur stosowanych przez państwa członkowskie w odniesieniu do powrotów nielegalnie przebywających obywateli państw trzecich (Dz.Urz. UE L 348, s. 98, ze zm.).

10 Convention for the Protection of Human Rights and Dignity of the Human Being with regard to the Application of Biology and Medicine: Convention on Human Rights and Biomedicine, CETS No. 164, dalej: Europejska Konwencja Biomedyczna, EKB.

11 Additional Protocol to the Convention on Human Rights and Biomedicine concerning Genetic Testing for Health Purposes, Strasbourg, 27.09.2008, Council of Europe Treaty Series - No. 203, dalej: Protokół IV. 
posażenie genetyczne ${ }^{12}$. Na gruncie omawianych norm prawnomiędzynarodowych odpowiedź wpisuje się jednak w szerszy problem statusu ludzkiego embrionu. Powołane traktaty Rady Europy używają na określenie podmiotu chronionego przed zakazem dyskryminacji genetycznej pojęcia „osoba”. Jest to znamienne ze względu na rozróżnienie w art. 1 ust. 1 EKB oraz w art. 1 ust. 1 Protokołu IV ,istoty ludzkiej” (human being, l’être humain), którą państwa-strony „chronią w jej godności i tożsamości”, i „osoby” (everyone, toute personne), której państwa-strony „gwarantują bez dyskryminacji, poszanowanie (...) integralności i innych podstawowych praw i wolności wobec zastosowań biologii i medycyny”. Rozróżnienie to ma fundamentalne konsekwencje. W świetle Sprawozdania wyjaśniającego do EKB pojęcie „istota ludzka” sięga swoim zakresem „zapoczątkowania życia”, ale treść terminu „osoba” uzależniona jest od prawa wewnętrznego państwa-strony ${ }^{13}$. W konsekwencji zakazy dyskryminacji genetycznej z art. 11 EKB i art. 17 ust. 1 Protokołu IV nie mają obligatoryjnego zastosowania do fazy prenatalnej, w tym również fazy przedimplantacyjnej w warunkach in vitro ${ }^{14}$.

W kwestii dostępu do diagnostyki przedimplantacynej wypowiadał się Europejski Trybunał Praw Człowieka ${ }^{15}$. W wyroku z 28 sierpnia 2012 r., wydanym w sprawie Costa i Pavan przeciwko Włochom, uznał za niespójny system prawa, który zakazuje selekcji embrionów in vitro w oparciu o diagnozę przedimplantacyjną w celu transferowania do organizmu kobiety embrionów wolnych od choroby genetycznej (mukowiscydozy), a z drugiej pozwala na aborcję płodu dotkniętego tą chorobą ( $\$ 64)$. Stanowisko to oparte zostało na - prezentowanej szeroko w literaturze $^{16}$ - argumentacji upatrującej poważniejsze skutki w aborcji ze wskazań embriopatycznych niż w diagnostyce przedimplantacyjnej ze względu na bardziej za-

Zob. A. Batteur, De la protection du corps à la protection de l'être humain. Les «anormaux» et les lois du 29 juillet 1994, „Petites Affiches” 1994, nr 149, s. 31; B. Feuillet-Le Mintier, Pouvoir parental et embryon, [w:] L'embryon humain. Approche multidisciplinaire, red. B. Feuillet-Le Mintier, Paris 1996, s. 218; J. F. Mattei, Les lois françaises dites de bioéthique: cinq ans après, „Recueil international de Législation sanitaire” 1999, nr 4, s. 630 .

Zob. Convention for the Protection of Human Rights and Dignity of the Human Being with regard to the Application of Biology and Medicine: Convention on Human Rights and Biomedicine, CETS No. 164, Explanatory Report (dalej: SW-EKB), pkt 18-19; P. Fraisseix, La protection de la dignité de la personne et de l'espèce humaines dans le domaine de la biomédecine: l'exemple de la convention d'Oviedo, „Revue internationale de droit comparé" 2000, nr 2, s. 391; R.-M. Lozano, La protection europeénne des droits de l'homme dans le domaine de la biomédecine, Paris 2001, s. 236-237; M. Grzymkowska, Standardy bioetyczne w prawie europejskim, Warszawa 2009, s. 177-178, 180; O. Nawrot, Ludzka biogeneza w standardach bioetycznych Rady Europy, Warszawa 2011, s. 148. Zob. O. Nawrot, Ludzka biogeneza..., s. 276.

15 Skarga nr 54270/10.

16 Zob. D. von Bülow, [w:] Genmedizin und Recht. Rahmenbedingungen und Regelungen für Forschung, Entwicklung, Klinik, Verwaltung, red. S. F. Winter, H. Fenger, H.-L. Schreiber, München 2001, s. 144, 150-151; R. K. Kutzer, Embryonenschutzesetz - Wertungswidersprüche zu den Regelungen bei Schwangerschaftsabbruch, Früheutanasie, Sterbenhilfe und Transplantation, „Medizinrecht” 2002, nr 1, s. 25; H. Sendler, Menschenwürde, PID und Schwangerschaftsabbruch, „Neue Juristische Wochenschrift” 2001, nr 30, s. 2149-2150. 
awansowany rozwój płodu i obciążenie psychiczne dla kobiety w tym pierwszym przypadku $(\$ 62, \$ 66)$. Nie jest ona wolna od uproszczeń wobec faktu, że przerwanie ciąży stanowi zazwyczaj odpowiedź na sytuację konfliktową już zastaną, a procedura zapłodnienia in vitro $\mathrm{z}$ diagnostyką przedimplantacyjną z góry taką konfliktową sytuację zakłada, kreując embriony „na próbę”, jako materiał do selekcji ${ }^{17}$. Zresztą nawet uznanie za niespójny systemu prawa, który zezwala na aborcję, a zakazuje diagnostyki przedimplantacyjnej, tak samo może prowadzić do podważenia względów embriopatycznych jako przesłanki aborcyjnej ${ }^{18}$. Z pewnością jednak przytoczony wyrok potwierdza wniosek, że zakazy dyskryminacji ze względów genetycznych przynajmniej co do zasady nie są postrzegane jako bariera dla diagnostyki przedimplantacyjnej.

Granice dopuszczalności diagnostyki przedimplantacyjnej nie zostały określone na poziomie traktatowym - poza art. $14 \mathrm{EKB}$, który za niedopuszczalne uznaje stosowanie medycznego wspomagania prokreacji w celu wyboru płci przyszłego dziecka z wyjątkiem, gdy ma to pozwolić na uniknięcie poważnej choroby dziedzicznej związanej z płcią $^{19}$. Brak bezpośredniej ochrony ludzkiego embrionu in vitro przed dyskryminacją genetyczną nie wyklucza jednak postawienia takich granic, dyktowanych ochroną jego godności jako „istoty ludzkiej” w rozumieniu art. 1 ust. 1 EKB ${ }^{20}$. Przytoczony art. 14 EKB sugerować może jako kryterium dopuszczalności diagnostyki przedimplantacyjnej możliwość wykrycia i dotkliwość choroby uwarunkowanej genetycznie. Jednakże nawet abstrahując od statusu ludzkiego embrionu, rozwiązanie takie nie jest wolne od zastrzeżeń. Wbrew pozorom pozostawia szeroki margines ocen arbitralnych już ze względu na możliwe różnice w wiarygodności badania genetycznego oraz $\mathrm{w}$ mocno zindywidualizowanych ocenach dotkliwości większości chorób możliwych do zdiagnozowania w fazie przedimplantacyjnej ${ }^{21}$. Co więcej, nasuwa obawy o społeczne postrzeganie niepełnosprawności uwarunkowanej genetycznie, wyrażające się zwłaszcza w traktowaniu narodzin dziecka dotkniętego zaburzeniami genetycznymi w kategoriach porażki prokreacyjnej. Pojawia się tu ryzyko stygmatyzacji osób lub grup w związku z cechami genetycznymi, któremu zapobieganie należy do obowiązków wynikających z Protokołu IV (art. 4 ust. 2) ${ }^{22}$.

\footnotetext{
17 Zob. E. Benda, Verstandigungsversuche über die Würde des Menschen, "Neue Juristische Wochenschrift” 2001, nr 30, s. 2147; M. Grzymkowska, Standardy bioetyczne..., s. 124-125.

Zob. E. Benda, Verstandigungsversuche über..., s. 2147.

Zob. art. 2 ust. 2 Protokołu IV, który wyraźnie wyłącza je spod zakresu tego traktatu.

Próby w tym kierunku podejmowano w soft law Rady Europy, zob. O. Nawrot, Ludzka biogeneza..., s. 249-251.

Zob. J. Haberko, Ustawa o leczeniu niepłodności. Komentarz, Warszawa 2016, s. 166-167; O. Nawrot, Ludzka biogeneza..., s. 274-275.

22 W odróżnieniu zaś od dyskryminacji stygmatyzacja nie musi odnosić się do wykonywania indywidualnego prawa, a raczej dotyczy sposobu, w jaki osoba lub grupa jest postrzegana w oparciu - w tym wypadku - o cechy genetyczne; zob. Explanatory Report to the Additional Protocol to the Convention on Human Rights and Biomedicine concerning Genetic Testing for Health Purposes, Strasbourg, 27.12.2008, pkt 42.
} 
Właściwe dla międzynarodowych standardów biomedycznych rozróżnienie godności istoty ludzkiej i praw osoby stwarza podstawy dla konstrukcji ochrony godności embrionu jako istoty ludzkiej bez uznania jego praw ${ }^{23}$. Kwestią wciąż otwartą pozostaje zakres tak rozumianej ochrony. $\mathrm{Na}$ gruncie międzynarodowym niewątpliwie jednak obejmuje ona takie interwencje na embrionie, które jednocześnie godzą w ludzki genom ${ }^{24}$. Wyraża się szczególnie w zakazie modyfikacji genetycznej komórek linii rozrodczej, który znalazł także odzwierciedlenie w art. $13 \mathrm{EKB}^{25}$. Przepis ten nie przewiduje wyjątków, nawet dla interwencji podejmowanych w celu leczniczym poza przypadkiem, gdy zmiany w genomie potomstwa stanowią wyłącznie uboczny skutek realizacji tego celu ${ }^{26}$.

\section{Perspektywa prawnoporównawcza}

W systemach prawa odnoszących się do diagnostyki przedimplantacyjnej dominującym rozwiązaniem jest uzależnienie jej dopuszczalności od zaistnienia określonych bliżej wskazań medycznych. Podstawowe znaczenie wśród nich ma odpowiednio wysokie ryzyko wystąpienia u dziecka wady genetycznej, powodującej skutki zdrowotne o poważnym stopniu dotkliwości ${ }^{27}$. Tytułem przykładu, prawo niemieckie wyłącza bezprawność diagnostyki genetycznej, jeśli z cech genetycznych kobiety lub mężczyzny, od których pochodzi gameta, lub ich obydwojga wynika wysokie ryzyko poważnej choroby genetycznej u potomstwa lub gdy celem tej interwencji jest ustalenie poważnych uszkodzeń embrionów, które z du-

Szerzej zob. wyrok ETPC w sprawie Vo przeciwko Francji z 8 lipca 2004 r., skarga nr 53924/00, § 84; R. Scott, The English fetus and the right to life, „European Journal of Health Law” 2004, nr 4, s. 348, 351-352, 354; Ch. Byk, La Convention européenne sur la biomédecine et les droits de l'homme et l'ordre juridique international, „Journal de droit international” 2001, nr 1, s. 63-64; M. Casini, /l diritto alla vita del concepito nella giurisprudenza europea, Padova 2001, s. 339-344.

24 Zob. P. Fraisseix, La protection..., s. 389, 391.

25 „Interwencja zmierzająca do modyfikacji ludzkiego genomu może być podjęta ze względów prewencyjnych, diagnostycznych lub terapeutycznych i jeśli jej celem nie jest wprowadzenie jakichkolwiek zmian w genomie potomstwa".

26 Zob. SW-EKB, pkt. 89-93; M. Belanger, Progrès médical et droit européen: la question des therapies génique et cellulaire humaines, [w:] Progrès médical et droit européen, red. L. Dubouis, Paris 1999, s. 60; M. Safjan, L. Bosek, Prawo a dylematy współczesnej genetyki, [w:] Biologia molekularna w medycynie. Elementy genetyki klinicznej, red. J. Bal, Warszawa 2017, s. 84.

27 Zob. np. art. L 2131-4 francuskiego Kodeksu zdrowia publicznego (Code de la santé publique), https://www.legifrance.gouv.fr, dalej c.s.p.; C. Neirinck, L'encadrement juridique de l'acte médical sur l'embryon humain, [w:] L'embryon humain. Approche multidisciplinaire, red. B. Feuillet-Le Mintier, Paris 1996, s. 81; B. B. Mathieu, Force et faiblesse des droits fondamenteaux comme instruments du droit de la bioéthique: le principe de dignité et les interventions sur le genome humain, „Revue du droit publique” 1999, nr 1, s. 109-110; art. 1 ZA (1) lit. a-c załącznika nr 2 do brytyjskiej Human Fertilisation and Embryology Act 1990, s. 37; The Public General Acts and General Synod Measures 1990, Part. IV, s. 1471 z późn. zm.; § 2a ust. 2 Gesetz zum Schutz von Embryonen (Embryonenschutzgesetz - ESchG) vom 13. Dezember 1990, BGBI. Nr 69, Teil I, s. 2746, z późn. zm.; art. 12 ust. 2 hiszpańskiej Ley 14/2006, de 26 de mayo, sobre técnicas de reproducción humana asistida BOE 2006, nr 126, s. 19947, z późn. zm. 
Zakaz dyskryminacji ze względu na wyposażenie genetyczne...

żym prawdopodobieństwem doprowadzą do śmierci lub poronienia ${ }^{28}$; w prawie hiszpańskim diagnostyka przedimplantacyjna może być przeprowadzona w celu wykrycia poważnych chorób dziedzicznych, dających objawy we wczesnym wie$\mathrm{ku}$, niemożliwych do leczenia po urodzeniu zgodnie $\mathrm{z}$ aktualną wiedzą medyczną, i wyselekcjonowania preembrionów wolnych od wad lub w celu wykrycia innych uszkodzeń, które mogą mieć wpływ na zdolność preembrionów do życia ${ }^{29}$. Od pierwszej dekady XXI w. do wymienionych wskazań ustawodawcy dodają opisaną w literaturze medycznej w 2001 r. - możliwość wykorzystania diagnostyki przedimplantacyjnej w celu wyselekcjonowania embrionu nie tylko wolnego od choroby genetycznej, ale zarazem nadającego się pod względem zgodności tkankowej do bycia po urodzeniu dawcą komórek macierzystych dla starszego rodzeństwa dotkniętego poważną chorobą ${ }^{30}$. Tytułem przykładu, art. L2131-4-1 francuskiego c.s.p. przewiduje, że w drodze wyjątków od ogólnych zasad dopuszczalności diagnostyki przedimplantacyjnej można ją przeprowadzić po uzyskaniu specjalnego zezwolenia Agencji Biomedycyny, jeśli z prokreacji medycznie wspomaganej korzystają rodzice dziecka dotkniętego chorobą genetyczną skutkującą śmiercią w pierwszych latach życia i uznaną za nieuleczalną w momencie diagnostyki, a szanse życiowe tego dziecka mogą być podwyższone w decydujący sposób w wyniku zastosowania u niego terapii niebędącej zamachem na integralność cielesną dziecka urodzonego w wyniku transferu embrionu.

Mimo ewolucji w kierunku poszerzania zakresu wskazań dla diagnostyki przedimplatacyjnej ich szczegółowy opis w ustawach stanowi niewątpliwie wyraz obaw przed arbitralnym doborem kryteriów selekcji embrionów w oparciu nie tylko o względy pozamedyczne, ale i o stan zdrowia. Obawy te są szczególnie obecne we Francji ze względu na ustawowy zakaz praktyk eugenicznych ${ }^{31}$, który ustawodawca zamieścił w kodeksie cywilnym (art. 16-4 c. civ.) oraz w kodeksie karnym (art. L 214-1 c. pén.), lokując go wśród przestępstw przeciwko ludzkości i gatunko-

28 Zob. § 3 a ust. 2 ESchG.

29 Zob. art. 12 ust. 2 Ley 14/2006, w której pojęcie preembrionu oznacza embrion in vitro od zapłodnienia do 14 dnia (art. 1 ust. 2).

30 Zob. S. Rechitsky et al., Preimplantation genetic diagnosis with HLA matching, „Reproductive BioMedicine Online" 2004, nr 2; A. Kuliev, Y. Verlinsky, Preimplantation genetic..., s. 535; art. L 2131-4-1 fr. c.s.p. wprowadzony przez Loi ${ }^{\circ}$ 2004-800 du 6 août 2004 relative à la bioéthique, „Le Journal officiel de la République française" (dalej JORF) 7 août 2004, n 182, s. 14040, z późn. zm.; art. 1 ZA (1) lit. d załącznika nr 2 do brytyjskiej HFEAct (dodanego w 2008); art. 12 ust. 2 hiszpańskiej Ley 14/2006; F. Abellán, Selección genética de embriones. Entre la libertad reproductive y la eugenesia, Granada 2007, s. 39-40; K. Bączyk-Rozwadowska, Aktualne problemy diagnostyki preimplantacyjnej w kontekście dążeń rodziców do realizacji projektu rodzicielskiego, „Białostockie Studia Prawnicze” 2017, nr 2, s. 20-24; M. Gałązka, Preimplantation genetic diagnosis: between an offence and a health service. A comparative legal perspective, „Review of Comparative Law” 2013, nr 18, s. 64-68.

31 Zob. J.-F. Mattei, Les avancées..., s. 456; A. Batteur, De la protection..., s. 30-31; R.-M. Lozano, La protection europeénne..., s. 301-307; C. Neirinck, L'encadrement juridique..., s. 79; B. Mathieu, Force et faiblesse..., s. 107-110; J. Testart, Des ovules en abondance?, „Médecine/Science” 2004, nr 11, s. 1044. 
wi ludzkiemu ${ }^{32}$ jako przestępstwo o następującym opisie: „zastosowanie praktyki eugenicznej zmierzającej do organizacji selekcji osób podlega karze do 30 lat więzienia (réclusion criminelle) i do 7500000 euro grzywny”. Chociaż nieokreśloność treści przytoczonego zakazu karnego nakazuje traktować go raczej w kategoriach kryminalizacji symbolicznej, to jednak znamienne jest to, że ustawodawca zdecydował się ustanowić ten zakaz w jednej z tzw. ustaw bioetycznych z 1994 r., wprowadzających kompleksową regulację prokreacji medycznie wspomaganej i odrębne przepisy karne chroniące embrion in vitro ${ }^{33}$.

W wielu systemach prawnych obowiązują też zakazy karne mające chronić przed ryzykiem modyfikacji genetycznej komórek linii rozrodczej. Nie wszyscy ustawodawcy podzielają jednak rygoryzm art. 13 EKB. Obok zakazów o charakterze bezwzględnym (w Szwajcarii i w Niemczech ${ }^{34}$ ) warto wskazać na prawo hiszpańskie $^{35}$, włoskie ${ }^{36}$ i francuskie ${ }^{37}$, które nie wykluczają genoterapii linii rozrodczej w celach terapeutycznych, oraz holenderskie, które dopuszcza możliwość manipulacji na genach zawartych w mitochondrium komórki jajowej ${ }^{38}$.

\section{Perspektywa krajowa}

Polskie prawo długo nie odnosiło się bezpośrednio do diagnostyki przedimplatacyjnej, chociaż art. $157 \mathrm{a} \$ 1 \mathrm{kk} .{ }^{39}$ dawał podstawy dla uznania za niedopuszczalną wszelkiej interwencji polegającej na pobraniu komórki lub komórek od embrio-

32 Przestępstwo to zostało zamieszczone w księdze II Kodeksu karnego pt. „Zbrodnie i występki przeciwko osobom”, tytule I „Zbrodnie przeciwko ludzkości i przeciwko gatunkowi ludzkiemu”, podtytuł II: „Zbrodnie przeciwko gatunkowi ludzkiemu".

33 Zob. Loi $n^{\circ}$ 94-653 du 29 juillet 1994 relative au respect du corps humain, JORF n`175 du 30 juillet 1994 , s. 11056 , art. 1 i 9.

34 Zob. art. 119 ust. 2 lit. a Constitution fédérale de la Confédération suisse du 18 avril 1999, Recueil officiel du droit fédéral 1999, s. 2556; art. 35 ust. 1 i art. 2 lit. f Loi fédérale sur la procréation médicalement assistée (LPMA) du 18 décembre 1998, Recueil officiel du droit fédéral 2000, s. 3055-3067, z późn. zm.; § 5 ust. 1 i § 8 ust. 3 ESchG. Zakazy te nie obejmują nieuniknionej (art. 35 ust. 3 LPMA) lub niezamierzonej ( 55 ust. 4 pkt 3 ESchG) modyfikacji wyposażenia dziedzicznego, będącą ubocznym skutkiem innego leczenia.

35 Zob. art. 159 ust. 1 Ley Orgánica 10/1995, de 23 de noviembre, del Código Penal, BOE 1995, nr 281, z późn. zm.; J.M. Tamarit Sumalla, [w:] Comentarios a la Parte Especial del Derecho Penal, red. G. Quintero Olivares, F. Morales Prats, Pamplona 2016, s. 162.

36 Zob. art. 13 ust. 3 lit. b. Legge 19 febbraio 2004, n. 40. Norme in materia di procreazione medicalmente assistita, Gazzetta Ufficiale n. 45 del 24.2.2004, ze zm.

37 Zob. art. 16-4 ust. 4 Kodeksu cywilnego (Code civil), https://www.legifrance.gouv.fr; A. Batteur, De la protection..., s. 30; J.-S. Cayla, La déclaration universelle sur le génome humain et les droits de l'homme, du 11 novembre 1997, et la législation française sur le respect du corps humain, „Revue de droit sanitaire et social” 1998, nr 1, s. 49.

38 Zob. art. 24 lit. g Wet van 20 juni 2002, houdende regels inzake handelingen met geslachtscellen en embryo's (Embryowet), Staatsblad van het Koninkrijk der Nederlanden 2002, 338, z późn. zm.

39 „Kto powoduje uszkodzenie ciała dziecka poczętego lub rozstrój zdrowia zagrażający jego życiu, podlega grzywnie, karze ograniczenia wolności albo pozbawienia wolności do lat 2". 
Zakaz dyskryminacji ze względu na wyposażenie genetyczne...

nu in vitro ${ }^{40}$. Diagnostyka przedimplantacyjna uzyskała akceptację systemu prawa dopiero w art. 26 ust. 1 zd. 1 ustawy z dnia 25 czerwca 2015 r. o leczeniu niepłodności ${ }^{41}$ o następującej treści: „Stosowanie preimplantacyjnej diagnostyki genetycznej w ramach procedury medycznie wspomaganej prokreacji jest dozwolone wyłącznie ze wskazań medycznych i poprzedza się tę diagnostykę poradnictwem genetycznym w ramach poradnictwa medycznego, o którym mowa w art. 5 ust. 1 pkt 1". W odróżnieniu od regulacji obowiązujących w prawie obcym polski ustawodawca nie określił, co należy rozumieć pod pojęciem wskazań medycznych ${ }^{42}$. Za ich treść można uznać zarówno oparte na jakiejkolwiek podstawie podejrzenie o istnieniu wady genetycznej embrionu, niezależnie od stopnia jej dotkliwości, jak i celowość wyselekcjonowania embrionu nadającego się po urodzeniu na dawcę przeszczepu dla rodzeństwa ${ }^{43}$. Jedyne ograniczenie dla omawianej interwencji sformułowano od strony negatywnej, w 26 ust. 2 u.l.n., zgodnie z którym „Niedopuszczalne jest stosowanie preimplantacyjnej diagnostyki genetycznej w ramach procedury medycznie wspomaganej prokreacji w celu wyboru cech fenotypowych, w tym płci dziecka, z wyjątkiem sytuacji, gdy wybór taki pozwala uniknąć ciężkiej, nieuleczalnej choroby dziedzicznej”. Przepis ten niewątpliwie nawiązuje do art. 14 EKB, chociaż wydaje się, że wskazany wyjątek dotyczyć może jedynie płci, nie zaś cech fenotypowych, które - w odróżnieniu od cech genetycznych - nie stanowią przyczyny choroby, a co najwyżej mogą być jej symptomem. Ostatecznie z perspektywy prawnoporównawczej granice diagnostyki przedimplantacyjnej zostały więc zakreślone w sposób wysoce nieprecyzyjny i zarazem szeroki ${ }^{44}$. Zarzut ten tym bardziej przybiera na znaczeniu, jeśli uwzględnić wątpliwości konstytucyjne, jakie nasuwa status ludzkiego embrionu in vitro (określnego mianem zarodka) w ustawie o leczeniu niepłodności w świetle konstytucyjnego standardu ochrony człowieka w fazie prenatalnej, wytyczonego orzeczeniem TK z dnia 28 maja 1997 r., ${ }^{45}$ szczególnie że dia-

40 Przepis ten bowiem, kryminalizując zamach na zdrowie człowieka w fazie prenatalnej, posługuje się ogólnym terminem „dziecko poczęte”, a zarazem uniezależnia jego dobra od sytuacji ciąży; szerzej zob. M. Gałązka, Prawnokarna ochrona ludzkiego embrionu in vitro, „Prokuratura i Prawo” 2007, nr 5, s. 30, 33-35; M. Żelichowski, Prawnokarna ocena pobierania embrionalnych komórek macierzystych, „Czasopismo Prawa Karnego i Nauk Penalnych” 2000, nr 2, s. 85; P. Daniluk, Ochrona zarodków powstałych w wyniku zapłodnienia pozaustrojowego na podstawie art. 157a kk., „Zeszyty Prawnicze BAS” 2010, nr 1, s. 12-14. Zastosowanie art. 157a $\S 1$ kk. do embrionu in vitro spotykało się też z krytyką, zob. zwłaszcza J. Kapelańska-Pręgowska, Prawne i bioetyczne aspekty testów genetycznych, Warszawa 2011, s. 240-241, 245; J. Majewski, Zakres prawnej ochrony embrionu in vitro na podstawie art. 157 § 1 ustawy z 6 czerwca 1997 r. - Kodeks karny, „Zeszyty Prawnicze BAS” 2010, nr 1, s. 22-29.

41 Zob. tekst jedn. Dz.U. z 2017 r. poz. 865; dalej: u.I.n.

42 Zob. K. Bączyk-Rozwadowska, Aktualne problemy..., s. 16.

43 Zob. też M. Soniewska, Selekcja genetyczna..., s. 153-154, 224-226, chociaż autorka słusznie podnosi wątpliwości na gruncie art. 23 ust. 3 u.I.n. wobec sytuacji, w której jedyną przyczyną rezygnacji z umieszczenia zarodków w organizmie kobiety byłby brak zgodności tkankowej z dzieckiem wymagającym przeszczepu.

44 Zob. J. Lipski, Opinia prawna na temat rządowego projektu ustawy o leczeniu niepłodności, „Zeszyty Prawnicze BAS" 2015, nr 4, s. 146.

45 K 26/96, OTK 1997, nr 2, poz. 19; szerzej zob. M. Gałązka, [w:] System prawa medycznego, red. M. Safjan, L. Bosek, t. 1, Warszawa 2018, s. 558-559, 652. 
gnostyka przedimplantacyjna funkcjonuje wyłącznie jako instrument selekcji embrionów, a ustawodawca nie podjął nawet próby nazwania racji, które uznaje za doniosłe na tyle, że na taką selekcję pozwalają. Ustawa nie wskazuje też bliżej na dopuszczalny stopień inwazyjności pobrania komórki od embrionu, mimo że w literaturze medycznej wyróżnia się w tym zakresie metody o zróżnicowanych skutkach.

Do genoterapii komórek linii rozrodczej prawo polskie również odniosło się bezpośrednio dopiero w ustawie z dnia 25 czerwca 2015 r. o leczeniu niepłodno$\mathrm{ści}^{46}$. Ocena tej interwencji nawiązuje do rygoryzmu art. $13 \mathrm{EKB}$. Zgodnie $\mathrm{z}$ art. 25 ust. 2 u.l.n. „interwencje mające na celu dokonanie dziedzicznych zmian w genomie ludzkim, które mogą być przekazane następnym pokoleniom" zostały objęte zakazem, którego naruszenie podlega kryminalizacji (art. 86 u.l.n.). Chociaż celowościowe ujęcie zabronionych czynności może nasuwać trudności interpretacyjne, to wydaje się jednak, że zakaz ten należy odnosić również do interwencji podejmowanych $\mathrm{w}$ celu leczniczym, jeśli $\mathrm{z}$ istoty swojej polegałyby na modyfikacji ludzkiej linii rozrodczej. Nie mieszczą się natomiast w jego zakresie zmiany genetyczne w linii rozrodczej, będące ubocznym skutkiem innej interwencji medycznej, np. radioterapii.

\section{Podsumowanie}

Interwencją z zakresu medycznego wspomagania prokreacji, która nasuwa najwięcej pytań na tle wolności od dyskryminacji genetycznej, jest diagnostyka przedimplantacyjna. Stanowi ona próbę przeciwdziałania chorobom uwarunkowanym genetycznie, ale w obecnym stanie medycyny pozwala na to w jeden tylko sposób - przez selekcję embrionów wolnych od wady genetycznej. Chociaż przewidziany w podstawowym kanonie międzynarodowych standardów biomedycznych zakaz dyskryminacji genetycznej nie ma zastosowania do ludzkiego embrionu in vitro, to jednak otwarty w ten sposób dostęp do diagnostyki przedimplantacyjnej nie jest wolny od problemu granic swojej dopuszczalności. Wytyczenie ich w oparciu o kryterium poważnych wad genetycznych embrionu nasuwa trudności wykładnicze i obawy o arbitralność ocen, a nadto wiąże się z ryzykiem stygmatyzacji osób dotkniętych chorobami uwarunkowanymi genetycznie. Problem ten nabiera szczególnego znaczenia w prawie polskim ze względu na brak bliższego określenia wskazań medycznych do diagnostyki przedimplantacyjnej oraz konstytucyjny status ludzkiego embrionu.

Możliwości terapii genowej komórek linii rozrodczej, która mogłaby być alternatywą wobec selekcji embrionów, wciąż niosą ze sobą wysoki potencjał ryzyka. 
Zakaz dyskryminacji ze względu na wyposażenie genetyczne...

Bezwzględny zakaz tej interwencji w Europejskiej Konwencji Biomedycznej uznany został jednak za zbyt radykalny przez szereg prawodawców krajowych, którzy decydują się na wprowadzenie wyjątku dla realizacji celów leczniczych.

\section{Akty prawne}

\section{Prawo międzynarodowe}

Additional Protocol to the Convention on Human Rights and Biomedicine concerning Genetic Testing for Health Purposes, Strasbourg, 27.XI.2008, European Treaty Series No. 203.

Convention for the Protection of Human Rights and Dignity of the Human Being with regard to the Application of Biology and Medicine: Convention on Human Rights and Biomedicine, Oviedo 4.IV.1997, European Treaty Series No 164.

Konwencja o ochronie praw człowieka i podstawowych wolności sporządzona w Rzymie dnia 4 listopada 1950 r., European Treaty Series No. 005 (Dz.U. z 1993 r. Nr 61, poz. 284 ze zm.).

\section{Prawo UE}

Karta Praw Podstawowych Unii Europejskiej (Dz.Urz. UE C 83 z dnia 30 marca 2010 r., s. 389-403).

Dyrektywa Parlamentu Europejskiego i Rady 2008/115/WE z dnia 16 grudnia 2008 r. w sprawie wspólnych norm i procedur stosowanych przez państwa członkowskie w odniesieniu do powrotów nielegalnie przebywających obywateli państw trzecich (Dz.Urz. UE L Nr 348, s. 98-107, ze zm.).

\section{Prawo poszczególnych państw - Polska}

Konstytucja Rzeczypospolitej Polskiej (Dz.U. z 1997 r. Nr 78, poz. 483 ze zm. i sprost.).

Ustawa z dnia 6 czerwca 1997 r. Kodeks karny (tekst jedn. Dz.U. z 2019 r. poz. 1950 ze zm.).

Ustawa z dnia 25 czerwca 2015 r. o leczeniu niepłodności (tekst jedn. Dz.U. z 2017 r. poz. 865 ze $\mathrm{zm}$.).

\section{Prawo poszczególnych państw - państwa obce}

Constitution fédérale de la Confédération suisse du 18 avril 1999, Recueil officiel du droit fédéral 1999, s. 2556.

Gesetz zum Schutz von Embryonen (Embryonenschutzgesetz - ESchG) vom 13. Dezember 1990, Bundesgesetzblatt Nr 69, Teil I, s. 2746, ze zm.

Human Fertilisation and Embryology Act 1990, c. 37, The Public General Acts and General Synod Measures 1990, Part. IV, s. 1471, ze zm.

Legge 19 febbraio 2004, n. 40. Norme in materia di procreazione medicalmente assistita, Gazzetta Ufficiale n. 45 del 24.2.2004, ze zm. 
Ley 14/2006, de 26 de mayo, sobre técnicas de reproducción humana asistida, Boletín Oficial del Estado 2006, nr 126, s. 19947 ze zm.

Ley Orgánica 10/1995, de 23 de noviembre, del Código Penal, Boletín Oficial del Estado 1995, nr 281, ze zm.

Loi fédérale sur la procréation médicalement assistée (LPMA) du 18 décembre 1998, Recueil officiel du droit fédéral 2000, s. 3055-3067, ze zm.

Loi $n^{\circ}$ 2004-800 du 6 août 2004 relative à la bioéthique, Journal officiel de la République française $\mathrm{n}^{\circ} 182,7$ août 2004, s. 14040 ze zm.

Loi $\mathrm{n}^{\circ}$ 94-653 du 29 juillet 1994 relative au respect du corps humain, Journal officiel de la République française $\mathrm{n}^{\circ} 175,30$ juillet 1994, s. 11056.

Wet van 20 juni 2002, houdende regels inzake handelingen met geslachtscellen en embryo's (Embryowet), Staatsblad van het Koninkrijk der Nederlanden 2002, 338, ze zm.

\section{Orzecznictwo}

Orzeczenie Trybunału Konstytucyjnego z 28 maja 1997 r., K 26/96, Orzecznictwo Trybunału Konstytucyjnego 1997, nr 2, poz. 19.

Wyrok Europejskiego Trybunału Praw Człowieka z 28 sierpnia 2012 r., w sprawie Costa i Pavan przeciwko Włochom, skarga nr 54270/10, dostęp za pośrednictwem wyszukiwarki HUDOC (https://hudoc.echr.coe.int).

Wyrok Europejskiego Trybunału Praw Człowieka z 8 lipca 2004 r., w sprawie Vo przeciwko Francji, skarga nr 53924/00, dostęp za pośrednictwem wyszukiwarki HUDOC (https://hudoc.echr.coe.int).

\section{Literatura}

Abellán F., Selección genética de embriones. Entre la libertad reproductive y la eugenesia, Granada 2007.

Bączyk-Rozwadowska K., Aktualne problemy diagnostyki preimplantacyjnej w kontekście dażeń rodziców do realizacji projektu rodzicielskiego, „Białostockie Studia Prawnicze" 2017, nr 2.

Barańska M., Skrętowicz J., Perspektywy terapii genowej, „Wiadomości Lekarskie” 2007, nr 7-8.

Batteur A., De la protection du corps à la protection de lêtre humain. Les «anormaux» et les lois du 29 juillet 1994, „Petittes Affiches” 1994, nr 149.

Belanger M., Progrès médical et droit européen: la question des therapies génique et cellulaire humaines, [w:] Progrès médical et droit européen, red. L. Dubouis, Paris 1999.

Benda E., Verstandigungsversuche über die Würde des Menschen, „Neue Juristische Wochenschrift" 2001, nr 30.

Bülow D. von, [w:] Genmedizin und Recht. Rahmenbedingungen und Regelungen für Forschung, Entwicklung, Klinik, Verwaltung, red. S. F. Winter, H. Fenger, H.-L. Schreiber, München 2001. 
Zakaz dyskryminacji ze względu na wyposażenie genetyczne...

Byk Ch., La Convention européenne sur la biomédecine et les droits de l'homme et l'ordre juridique international, „Journal de droit international” 2001, nr 1.

Casini M., Il diritto alla vita del concepito nella giurisprudenza europea, Padova 2001.

Cayla J.-S., La déclaration universelle sur le génome humain et les droits de l'homme, du 11 novembre 1997, et la législation française sur le respect du corps humain, „Revue de droit sanitaire et social" 1998, nr 1.

Cimadomo D. et al., The impact of biopsy on human embryo developmental potential during preimplantation genetic diagnosis, „BioMed Research International” 2016, article ID 7193075.

Comentarios a la Parte Especial del Derecho Penal, red. G. Quintero Olivares, F. Morales Prats, Pamplona 2016.

Daniluk P., Ochrona zarodków powstałych w wyniku zapłodnienia pozaustrojowego na podstawie art. 157a kk., „Zeszyty Prawnicze BAS” 2010, nr 1.

Explanatory Report to the Additional Protocol to the Convention on Human Rights and Biomedicine concerning Genetic Testing for Health Purposes, Strasbourg, 27.12.2008.

Feuillet-Le Mintier B., Pouvoir parental et embryon, [w:] Lembryon humain. Approche multidisciplinaire, red. B. Feuillet-Le Mintier, Paris 1996.

Folscheid D., Wunenburger J.-J., La vie commençante, [w:] Philosophie, éthique et droit de la médecine, red. D. Folscheid, B. Feuillet-Le Mintier, J.-F. Mattei, Paris 1997.

Fraisseix P., La protection de la dignité de la personne et de l'espèce humaines dans le domaine de la biomédecine: l'exemple de la convention d'Oviedo, „Revue internationale de droit comparé" 2000, nr 2.

Gałązka M., [w:] System prawa medycznego, red. M. Safjan, L. Bosek, t. 1, Warszawa 2018.

Gałązka M., Prawnokarna ochrona ludzkiego embrionu in vitro, „Prokuratura i Prawo” 2007, nr 5.

Gałązka M., Preimplantation genetic diagnosis: between an offence and a health service. A comparative legal perspective, ,Review of Comparative Law” 2013, nr 18.

Genmedizin und Recht. Rahmenbedingungen und Regelungen für Forschung, Entwicklung, Klinik, Verwaltung, red. S.F. Winter, H. Fenger, H.-L. Schreiber, München 2001.

Grzymkowska M., Standardy bioetyczne w prawie europejskim, Warszawa 2009.

Haberko J., Ustawa o leczeniu niepłodności. Komentarz, Warszawa 2016.

Handyside A.H., Preimplantation genetic diagnosis after 20 years, „Reproductive BioMedicine Online" 2010, nr 3.

Harton G. et al., ESHRE PGD Consortium/Embryology Special Interest Group - best practice guidelines for polar body and embryo biopsy for preimplantation genetic diagnosis/ screening (PGD/PGS), „Human Reproduction” 2011, nr 1.

Kapelańska-Pręgowska J., Prawne i bioetyczne aspekty testów genetycznych, Warszawa 2011.

Kuliev A., Verlinsky Y., Thirteen years' experience of preimplantation diagnosis: report of the Fifth International Symposium on Preimplantation Genetics, „Reproductive BioMedicine Online” 2003, nr 2. 
Kuliev A., Verlinsky Y., Preimplantation genetic diagnosis: technological advances to improve accuracy and range of applications, „Reproductive BioMedicine Online” 2008, nr 4.

Kutzer R.K., Embryonenschutzesetz - Wertungswidersprüche zu den Regelungen bei Schwangerschaftsabbruch, Früheutanasie, Sterbenhilfe und Transplantation, „Medizinrecht" 2002, nr 1.

Lipski J., Opinia prawna na temat rządowego projektu ustawy o leczeniu niepłodności, „Zeszyty Prawnicze BAS” 2015, nr 4.

Lozano R.-M., La protection europeénne des droits de l'homme dans le domaine de la biomédecine, Paris 2001.

Lu L. et al., Recent advances in preimplantation genetic diagnosis and screening, „Journal of Assisted Reproduction and Genetics" 2016, nr 9.

Lunsho J.E., Human germ line editing - roles and responsibilities, „Protein Cell” 2016, nr 7.

Majewski J., Zakres prawnej ochrony embrionu in vitro na podstawie art. $157 \$ 1$ ustawy z 6 czerwca 1997 r. - Kodeks karny, „Zeszyty Prawnicze BAS” 2010, nr 1.

Mathieu B., Force et faiblesse des droits fondamenteaux comme instruments du droit de la bioéthique: le principe de dignité et les interventions sur le genome humain, „Revue du droit publique" 1999, nr 1.

Mattei J.-F., Les lois françaises dites de bioéthique: cinq ans après, „Recueil international de législation sanitaire" $1999, \mathrm{nr} 4$.

Mattei J.-F., Les avancées de la génétique, [w:] Philosophie, éthique et droit de la médecine, red. D. Folscheid, B. Feuillet-Le Mintier, J.-F. Mattei, Paris 1997.

Misra S., Human gene therapy: a brief overview of the genetic revolution, „Association of Physicians of India" 2013, nr 2.

Narayanan G. et al., Clinical development of gene therapy needs a tailored approach: a regulatory perspective from the European Union, „Human Gene Therapy Clinical Development" 2014, nr 1.

Nawrot O., Ludzka biogeneza w standardach bioetycznych Rady Europy, Warszawa 2011.

Neirinck C., L'encadrement juridique de l'acte médical sur l'embryon humain, [w:] L'embryon humain. Approche multidisciplinaire, red. B. Feuillet-Le Mintier, Paris 1996.

Rechitsky S. et al., Preimplantation genetic diagnosis with HLA matching, „Reproductive BioMedicine Online" 2004, nr 2.

Safjan M., Bosek L., Prawo a dylematy współczesnej genetyki, [w:] Biologia molekularna w medycynie. Elementy genetyki klinicznej, red. J. Bal, Warszawa 2017.

Scott R., The English Fetus and the Right to Life, „European Journal of Health Law” 2004, nr 4.

Sendler H., Menschenwürde, PID und Schwangerschaftsabbruch, „Neue Juristische Wochenschrift" 2001, nr 30.

Soniewska M., Selekcja genetyczna w prokreacji medycznie wspomaganej. Etyczne i prawne kryteria, Warszawa 2018. 
System prawa medycznego, t. 1: Instytucje prawa medycznego, red. M. Safjan, L. Bosek, Warszawa 2017.

Tamarit Sumalla J.M., [w:] Comentarios a la Parte Especial del Derecho Penal, red. G. Quintero Olivares, F. Morales Prats, Pamplona 2016.

Testart J., Des ovules en abondance?, „Médecine/Science” 2004, nr 11.

Theodosiou A.A., Johnson M.H., The politics of human embryo research and the motivation to achieve PGD, „Reproductive BioMedicine Online” 2011, nr 22, nr 5.

Żelichowski M., Prawnokarna ocena pobierania embrionalnych komórek macierzystych, „Czasopismo Prawa Karnego i Nauk Penalnych” 2000, nr 2. 